\title{
Preference for oils with different types of genetic modifications in Temuco, Araucanía Region, Chile
}

\author{
Berta Schnettler ${ }^{1}$, Abel González ${ }^{2}$, Richard Avila ${ }^{1}$, Horacio Miranda ${ }^{1}$, José \\ Sepúlveda ${ }^{3}$, and Marianela Denegri ${ }^{3}$ \\ ${ }^{1}$ Department of Agricultural Production, ${ }^{2}$ Master in Agribusiness Management and \\ ${ }^{3}$ Department of Psychology, Universidad de La Frontera, Casilla 54-D, Temuco, Chile.
}

\begin{abstract}
B. Schnettler, A. González, R. Avila, H. Miranda, J. Sepúlveda, and M. Denegri. 2010. Preference for oils with different types of genetic modifications in Temuco, Araucanía Región, Chile. Cien. Inv. Agr. 37(1):17-28. Considering that attitudes towards biotechnology depend on the type of modification used, a study was performed to determine the importance of the type of Genetic Modification (GM) in preferences for oil purchased by consumers in Temuco (Araucanía Region, Chile) and the existence of different market segments using a survey of 400 people. A conjoint analysis demonstrated that the type of GM (70.3\%) was more important than the price of the oil (29.7\%). Four segments were distinguished using an analysis of hierarchical conglomerates, but the type of GM was the most important factor in all segments. Two groups preferred oil without GM and oil with GM that reduces the use of pesticides and rejected oil with GM that increases calcium content; the larger of these groups $(42.8 \%)$ preferred to pay a lower price, while the other (16.8\%) they preferred higher priced oils. One group (27.2\%) rejected all types of GM. The smallest group (13.2\%) rejected oil without GM and preferred oil with GM that reduces the use of pesticides and oil with GM that increases calcium. All of the groups rejected oil with GM that reduces production costs. The groups were differentiated by the family size, lifestyle, ethnic origin, reading of the labels on foodstuffs, and the variety of oil habitually consumed. The absence of GM in oils is desirable for the majority of consumers (86.8\%); however, a high proportion (72.8\%) would accept oils with GM that reduces the use of pesticides.
\end{abstract}

Key words: oil, transgenic foodstuffs, market segmentation, type of genetic modification.

\section{Introduction}

Numerous studies show that the majority of consumers prefer food without genetic manipulation (GM) and reject transgenic food (TF) (Terawaki, 2008; Ganiere et al., 2006; Capo- rale and Monteleone, 2004; Mucci et al., 2004). However, there is evidence that some groups of consumers have a positive attitude towards $\mathrm{TF}$, mainly in developing countries (Kimenju and De Groote, 2008, Mucci and Hough, 2003; Pachico and Wolf, 2002; Zhong et al., 2002; Da Costa et al., 2000).

Attitudes towards biotechnology depend on the organism in which it is applied and the type and objective of the genetic modification. For 
example, GMs in plants or microorganisms are more accepted than modifications in animals (Nayga et al., 2006, Frewer et al., 2004). Likewise, modifications that reduce the use of pesticides are more accepted than modifications that only reduce costs (Kaye-Blake et al., 2005). The GMs are more accepted when they have benefits for the consumer (Hossain et al., 2003; Lähteenmäki et al., 2003).

The consumer's attitude towards TF is partly determined by the perceived risks and benefits (Christoph et al., 2008). Substantial benefits, such as lower price (Kaye-Blake et al., 2005, Hossain et al., 2003), higher nutritional value (Kaye-Blake et al., 2005; Mucci et al., 2004; Lähteenmäki et al., 2003), and lower environmental impact (Ganiere et al., 2006; Kaye-Blake et al., 2005; Napier et al., 2004; Lähteenmäki et al., 2003), among others, would compensate for perceived risks, resulting in a positive attitude towards the TF. Nevertheless, other studies refer to a negative attitude towards TF that is not offset by the health benefits (Grunert et al., 2001) or a lower price (Terawaki, 2008; Caporale and Monteleone, 2004). Some researchers have concluded that the acceptance of TF is associated with consumer characteristics, such as gender (Christoph et al., 2008; Ganiere et al., 2006; Nayga et al., 2006; Napier et al., 2004; Hossain et al., 2003), age (Kimenju and De Groote, 2008; Ganiere et al., 2006; Nayga et al., 2006; Napier et al., 2004; Hossain et al., 2003), education (Kimenju and De Groote, 2008; Ganiere et al., 2006; Mucci et al., 2004), and lifestyle (Nayga et al., 2006; Hossain et al., 2003). There is also evidence that distinct consumer segments exist based on the attitude towards TF (Boecker et al., 2008; Christoph et al., 2008, Ganiere et al., 2006), of which some are in favor of and others are against TFs.

The use of applied biotechnology in agriculture is strategically important for developing countries, whose economy is based on natural resources (Mucci et al., 2004). In 2002, the National Biotechnology Policy was developed in Chile to stimulate the development and application of biotechnology, particularly in the productive sectors based on natural resources. Since then, many projects that incorporate biotechnological tools to optimize the quality of products or increase the efficiency of production processes have been approved. As a result, Chilean agriculture is expected to reach levels of competition and efficiency that will enable it to participate in national and international markets. Nevertheless, little is known about Chilean consumer preferences, and international signs of rejection have not been heeded (Mucci et al., 2004).

In Santiago, Chile, a negative public perception about the use of TF has been found (Gil et al., 2001). More recently, in Temuco and Talca, consumer groups with different levels of acceptance of TFs and different profiles for gender, age, size and family composition, socioeconomic group, area of residence, and lifestyle were recognized. However, neither study explained the type of GM present in the food (Schnettler et al., 2008a, b). Taking into consideration these precedents, the objective of this study was to determine the importance of the type of GM in preferences for vegetable oil among the consumers of Temuco (Araucanía Region, IX Region, Chile) and to differentiate market segments in relation to the acceptance of different types of GM.

\section{Materials and methods}

Survey

A personal survey was conducted in cohort of 400 consumers that were older than 18 years old from Temuco $\left(38^{\circ} 45^{\prime} \mathrm{S}, 73^{\circ} 03^{\prime} \mathrm{W}\right)$ and responsible for buying food for their home. The number of respondents was obtained through a simple random sampling formula for non-finite populations ( $\mathrm{N}>100,000 ; 245,347$ habitants of Temuco reported in the 2002 Census), considering a $95 \%$ confidence level and 5\% standard error with $\mathrm{p}$ and $\mathrm{q}$ of 0.5 (Fernández, 2002).

A closed-ended questionnaire was used to determine if the respondent had received information about TFs, if they knew its definition, the variety of oil consumed daily in the home, and the frequency that the respondent reads labels of food before purchase. Then, the respondents were provided the following definition of TFs: 
"Transgenic foods are those in which an artificial form of a foreign gene has been introduced at the embryonic level, so that the food retains this new characteristic during reproduction; for example, the gene could eliminate the use of pesticides, fungicides, and herbicides during cultivation." Afterward, they were asked if they thought it was necessary for the label to indicate that the food contains GM ingredients. The following classification questions were also included in the questionnaire: gender, age, family group size, the presence of children and their ages, lifestyle, ethnic origin, occupation and level of education of the head of the household, and the possession of 10 household goods. The last two variables were included to determine the socioeconomic group, which was classified as $\mathrm{ABC} 1$ (high and middle high), $\mathrm{C} 2$ (middle-middle), C3 (middle-low), D (low), and E (very low) (Anonymous, 2004). The survey was carried out in two supermarkets of Temuco between January and March 2008, after the questionnaire had been validated through a preliminary test with $10 \%$ of the cohort to be surveyed.

\section{Statistical analysis}

The importance of the type of genetic manipulation in the decision to buy oil was determined by a conjoint analysis (Hair et al., 1999). This analysis made it possible to determine the importance of the following attributes and levels: 1. the type of GM, including a. no genetic manipulation, b. genetic manipulation that reduces the use of herbicides during cultivation of the raw material used for oil production, c. genetic manipulation that increases calcium intake from the oil, and d. genetic manipulation that reduces the crop production costs of the raw material used for the oil; 2. the price per liter, with the levels of a. $\$ 680$ and b. $\$ 1,020$. The prices were established according to the average consumer sale prices $( \pm 10 \%)$ between January and October 2007 (ODEPA, 2007). Nevertheless, because a previous study indicated that the most preferred option corresponded to food without GM at the lowest price (Schnettler et al., 2008a,b), the option of oil without genetic manipulation at $\$ 680$ per liter was eliminated.
Therefore, the number of options presented to the respondents was reduced from eight to seven, and a fractional factorial design was used (Hair et al., 1999). The preference function corresponded to the Ideal Point Model (Hair et al., 1999). Seven cards with a specification for each attribute were developed. Each respondent ordered the cards from the most to the least preferable using a scale from 1 to 7 , where 1 was the most preferred and 7 the least preferred. For the price attribute, a linear relationship was established. The type of GM was considered a discrete variable. To determine the goodness of fit of the model, the Pearson correlation was used, and the Kendall Tau correlation was used to evaluate whether the ranking of the stimuli, which was determined according to the ranking function, corresponded with the real ranking of the respondent (Hair et al., 1999).

To determine the consumer segments according to the importance and preference for the type of GM in oil and price, a hierarchical cluster analysis was performed using Ward's method as a form of linking and the square root of the Euclidean distance as a measurement of similarity between objects (Hair et al., 1999). The number of clusters was obtained by determining the percentage change of the recomposed clustering coefficients. To describe the segments, the Pearson Chi Square $(\chi 2)$ test was applied to the discrete variables, and the unifactorial analysis of variance was used for the values of importance of the attributes and the preferences of the levels of the attributes for $p \leq 0.05$. The means of the variables with significant differences ( $p$ $\leq 0.05$ ) were compared using Tukey's multiple comparison test (Lea et al., 1997). The statistical analyses were performed with the SPSS 16.0 software (SPSS Inc., Chicago, USA).

\section{Results}

In the sample of consumers interviewed, there was a slight majority of women and the consumers were predominantly younger than 54 years old, had families with three to four members, resided in an urban setting, did not have children, were employed, led a conservative lifestyle, were from the $\mathrm{C} 2$ (middle-middle) socioeconomic group, and were non-Mapuche (Table 1). 
Table 1. Description in percentage of the sample of habitual supermarket consumers in Temuco, IX ${ }^{\text {th }}$ Region, Chile. March, 2008.

\begin{tabular}{|c|c|c|}
\hline & Composition & $\begin{array}{c}\text { Total sample } \\
(\mathrm{n}=400) \\
\%\end{array}$ \\
\hline Sample & Female & 56.0 \\
\hline \multirow[t]{3}{*}{ Gender } & Male & 44.0 \\
\hline & $<35$ years & 43.5 \\
\hline & $35-54$ years & 45.2 \\
\hline \multirow[t]{3}{*}{ Age } & 55 years or more & 11.2 \\
\hline & 1-2 family members & 27.2 \\
\hline & 3-4 family members & 60.5 \\
\hline \multirow[t]{2}{*}{ Family size } & 5 or more & 12.2 \\
\hline & Urban & 91.5 \\
\hline \multirow[t]{5}{*}{ Residence } & Rural & 8.5 \\
\hline & Without children & 34.8 \\
\hline & Children $<5$ years & 15.8 \\
\hline & Children 5-12 years & 9.2 \\
\hline & Children $13-17$ years & 19.5 \\
\hline \multirow[t]{7}{*}{ Presence and age of the children } & Children $\geq 18$ years & 20.8 \\
\hline & Self-employed & 21.0 \\
\hline & Entrepreneur & 3.0 \\
\hline & Employee & 27.8 \\
\hline & Public employee & 22.2 \\
\hline & Retired & 12.5 \\
\hline & Unemployed & 8.0 \\
\hline \multirow[t]{5}{*}{ Occupation } & Other situation & 5.5 \\
\hline & Conservative & 63.8 \\
\hline & Liberal & 15.2 \\
\hline & Vegetarian & 2.5 \\
\hline & Sport & 5.0 \\
\hline \multirow[t]{2}{*}{ Lifestyle } & Innovative & 13.5 \\
\hline & Mapuche & 5.2 \\
\hline \multirow[t]{5}{*}{ Ethnic group } & Non mapuche & 94.8 \\
\hline & ABC1 (high and middle-high) & 21.5 \\
\hline & C2 (middle-middle) & 46.5 \\
\hline & C3 (middle-lower) & 26.8 \\
\hline & D (lower) & 5.0 \\
\hline \multirow[t]{2}{*}{ Socioeconomic group } & E (very low) & 0.2 \\
\hline & Yes & 73.5 \\
\hline \multirow[t]{2}{*}{ Ha received information regarding $\mathrm{TF}^{1}$} & No & 26.5 \\
\hline & Yes & 29.5 \\
\hline \multirow[t]{5}{*}{ Know the meaning of $\mathrm{TF}^{1}$} & No & 70.5 \\
\hline & Always & 6.0 \\
\hline & Generally & 31.2 \\
\hline & Occasionally & 45.2 \\
\hline & Almost never & 13.2 \\
\hline \multirow[t]{2}{*}{ Frequency of reading food labels } & Never & 4.2 \\
\hline & Yes & 99.2 \\
\hline \multirow[t]{5}{*}{ The label must indicate the use of $\mathrm{GM}^{2}$ ingredients in the food } & No & 0.8 \\
\hline & Sunflower & 35.8 \\
\hline & Olive & 8.8 \\
\hline & Grape seed & 0.2 \\
\hline & Soy bean & 1.2 \\
\hline Variety of oil & Vegetal & 54.0 \\
\hline
\end{tabular}

${ }^{1} \mathrm{TF}$ : transgenic foods.

${ }^{2} \mathrm{GM}$ : genetic modification. 
Approximately $74 \%$ of the interviewees indicated that they had received information about $\mathrm{TF}$, but only $29.5 \%$ could give a definition. In relation to labeling, the proportions of consumers who indicated that they "generally" and "occasionally" read food labels were higher, while the majority agreed that the label should indicate the use of GM ingredients in the production of the food. The proportion of interviewees that regularly consume vegetable oil and sunflower oil was higher (Table 1).

The results of the conjoint analysis showed that the most important factor in buying oil was ence numbers) for the oil at a higher price, indicating that there was no association between price and quality (Figure 1). The Pearson and Kendall Tau correlation coefficients were equal to $1(\mathrm{p}=0.001)$. Through the cluster analysis, it was possible to significantly distinguish $(\mathrm{p} \leq$ 0.05 ) between four groups of consumers based on the importance and preference for the type of GM and price of oil (Table 2). The groups differed significantly according to the size of the family, lifestyle, ethnic origin, frequency of food label reading $(\mathrm{p} \leq 0.05)$, and the variety of oil consumed regularly at home $(\mathrm{p} \leq 0.001)$ (Table 3).
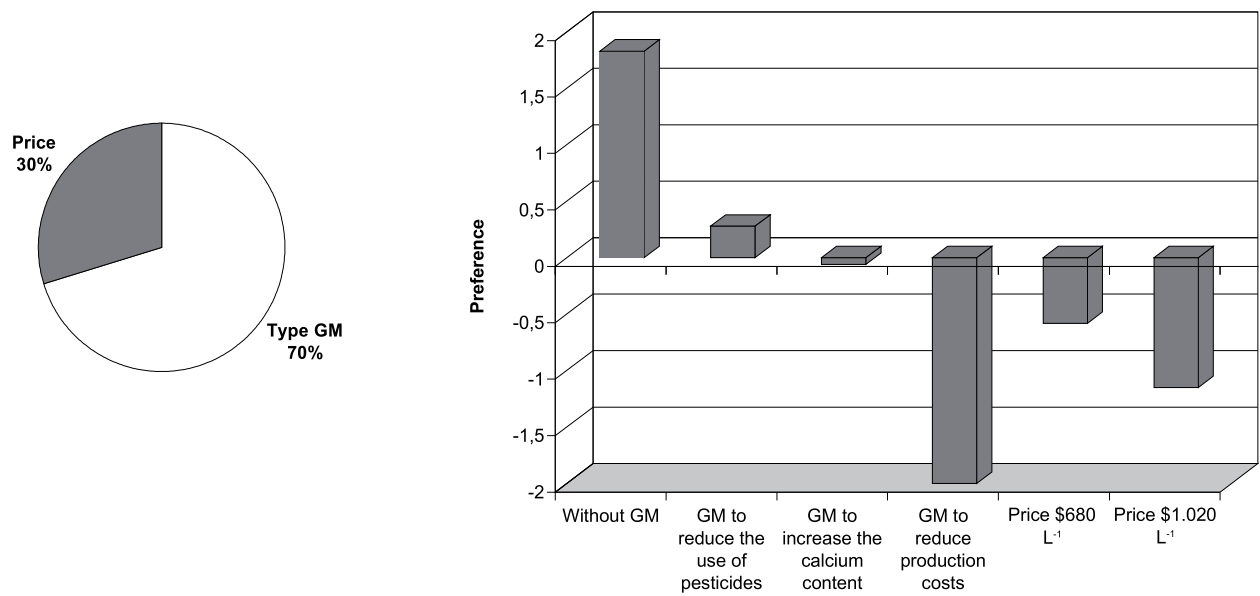

Figure 1. Importance of type of genetic manipulation (GM) and price in the decision to purchase vegetable oil and utilities of the levels of attribute in the total sample, IXth Region, Chile. March, 2008.

the type of GM used (70.3\%). The preference values for the levels of this attribute showed a preference for oil without GM and for oil with GM that reduces the use of pesticides (positive preferences) and rejection of oil with GM that increases calcium intake and with GM that reduces the cost of production (negative preferences). The magnitudes of preference for oil without GM and oil with GM that reduces the use of pesticides indicated a higher preference for oil without GM. In addition, the magnitudes of the preferences showed a higher rejection for oil with GM that reduces the cost of production than for oil with GM that increases calcium intake. Both price levels reported rejection, which increased (more negative prefer-
The largest group (Group 2), which represented $42.8 \%(n=171)$ of the sample of interviewees, placed a higher importance on the type of GM (85.3\%), and this was significantly higher than the other groups. The positive preference value for oil without GM (2.57) showed that the preference for this oil was significantly higher than in the other groups. This group also preferred oil with GM that reduces the use of pesticides, but the preference value (0.42) was significantly lower than Group 3, higher than Group 1, and similar to Group 4. The negative preference values for oil with GM that increases the content of calcium and for oil with GM that reduces the cost of production $(-0.28$ and -2.71 , respectively) showed rejection for both types of GM. 
Table 2. Importance of type of genetic manipulation $(\mathrm{GM})$ and price in the decision to purchase vegetable oil, and utilities of the levels of attribute in the groups obtained by cluster analysis in Temuco, IX ${ }^{\text {th }}$ Region, Chile. March, 2008.

\begin{tabular}{|c|c|c|c|c|c|c|}
\hline & $\begin{array}{l}\text { Group 1 } \\
\mathrm{n}=109\end{array}$ & $\begin{array}{l}\text { Group } 2 \\
\mathrm{n}=171\end{array}$ & $\begin{array}{l}\text { Group } 3 \\
\mathrm{n}=53\end{array}$ & $\begin{array}{l}\text { Group } 4 \\
n=67\end{array}$ & $\mathrm{~F}$ & $\mathrm{p}$ \\
\hline \multicolumn{7}{|l|}{ Importance of the attributes } \\
\hline Type of GM & $55.6 \mathrm{c}^{2}$ & $85.3 \mathrm{a}$ & $75.8 \mathrm{~b}$ & $51.3 \mathrm{c}$ & 493.850 & $\leq 0.001$ \\
\hline Price & $44.4 \mathrm{a}$ & $14.7 \mathrm{c}$ & $24.3 \mathrm{~b}$ & $48.7 \mathrm{a}$ & 487.472 & $\leq 0.001$ \\
\hline \multicolumn{7}{|c|}{ Preference for each level of the attributes ${ }^{1}$} \\
\hline Without GM & $2.20 \mathrm{a}$ & $2.57 \mathrm{a}$ & $-0.60 \mathrm{c}$ & $1.25 \mathrm{~b}$ & 102.955 & $\leq 0.001$ \\
\hline GM to reduce the use of pesticides & $-0.37 \mathrm{c}$ & $0.42 \mathrm{~b}$ & $1.19 \mathrm{a}$ & $0.26 \mathrm{~b}$ & 37.926 & $\leq 0.001$ \\
\hline GM to increase the calcium content & $-0.15 b$ & $-0.28 b$ & $0.84 \mathrm{a}$ & $-0.09 b$ & 18.556 & $\leq 0.001$ \\
\hline GM to reduce production costs & $-1.68 b$ & $-2.71 \mathrm{c}$ & $-1.17 \mathrm{a}$ & $-1.37 a b$ & 89.834 & $\leq 0.001$ \\
\hline Price $\$ 680 \mathrm{~L}^{-1}$ & $-3.31 \mathrm{c}$ & $-0.15 b$ & $-0.66 \mathrm{~b}$ & $2.84 \mathrm{a}$ & 706.992 & $\leq 0.001$ \\
\hline Price $\$ 1,020 \mathrm{~L}^{-1}$ & $-6.62 c$ & $-0.29 b$ & $-1.27 \mathrm{~b}$ & $5.69 \mathrm{a}$ & 702.930 & $\leq 0.001$ \\
\hline
\end{tabular}

${ }^{1}$ Utility numbers in the different levels from an attribute with a negative sign indicate utility loss for the consumer.

${ }^{2}$ Means followed by the same letters in each row are not statistically different between each other according to the Tukey's multiple comparison test $(\mathrm{p} \leq 0.05)$.

The rejection of oil with GM that increases the content of calcium was similar to Groups 1 and 4 and lower than Group 3. The negative preference value for oil with GM that reduces the cost of production was significantly lower than the rest of the groups, showing the highest rejection for this type of GM (Table 2). Group 2 showed a lower proportion of families with three or four members (53.8\%) and vegetarian lifestyles $(0.6 \%)$ and a higher proportion of people who read food labels only occasionally (55.6\%) (Table 3). According to these results, Group 2 can be considered consumers that are sensitive to the type of GM and show high rejection of the TF that reduce production costs.

The second group (Group 1) was numerically important because it represented 27.3\% ( $\mathrm{n}=$ 109) of the cohort and also assigned greater importance to the type of GM (55.6\%), although this was statically lower than for Groups 2 and 3 and similar to Group 4. The importance assigned to price (44.4\%) was significantly greater than Groups 2 and 3 and similar to Group 4. The preference for oil without GM was statistically similar to Group 2 and higher than Groups 3 and 4. This group rejected the three types of GM, although the negative preference value for the oil with GM that reduces the use of pesticide was significantly lower than the other groups. The rejection of the GM that increases the content of calcium was similar to Groups 2 and 4 and lower than Group 3, while the negative preference value for GM that reduces the cost of production was higher than Group 2, lower than Group 3, and similar to Group 4. This group presented the highest levels of rejection for both levels of price and also showed great sensitivity to their variations (Table 2). In relation to the total cohort, this group had a lower proportion of families with five or more members (6.4\%), an innovative lifestyle (7.3\%), and regularly consumed olive oil (3.7\%) (Table 3). According to these results, Group 1 can be considered the consumers that are sensitive to GM type and price and reject $\mathrm{TF}$.

The third group (Group 4) represented 16.8\% $(n=67)$ of the total respondent sample. Even if this group assigned little importance to the type of GM (51.3\%), they gave greater relevance to price $(48.7 \%)$, which was significantly higher than Groups 2 and 3 but similar to Group 1. Similarly to Group 2, this segment showed a preference for oil without GM and with GM that reduces the use of pesticide and rejected 
Table 3. Characteristics with significant differences in the groups of consumers identified by cluster analysis in Temuco, Chile. March, 2008.

\begin{tabular}{|c|c|c|c|c|}
\hline Characteristic & $\begin{array}{l}\text { Group } 1 \\
\mathrm{n}=109\end{array}$ & $\begin{array}{l}\text { Group } 2 \\
\mathrm{n}=171\end{array}$ & $\begin{array}{l}\text { Group } 3 \\
\mathrm{n}=53\end{array}$ & $\begin{array}{l}\text { Group } 4 \\
n=67\end{array}$ \\
\hline Family size & $\mathrm{p}=0.017^{1}$ & & & \\
\hline $1-2$ family members & 33.0 & 31.0 & 20.8 & 13.4 \\
\hline 3-4 family members & 60.6 & 53.8 & 67.9 & 71.6 \\
\hline 5 or more & 6.4 & 15.2 & 11.3 & 14.9 \\
\hline Lifestyle & $\mathrm{p}=0.020^{1}$ & & & \\
\hline Conservative & 70.6 & 67.3 & 62.3 & 44.8 \\
\hline Liberal & 16.5 & 12.9 & 15.1 & 19.4 \\
\hline Vegetarian & 3.7 & 0.6 & 3.8 & 4.5 \\
\hline Sport & 1.8 & 6.4 & 5.7 & 6.0 \\
\hline Innovative & 7.3 & 12.9 & 13.2 & 25.4 \\
\hline Ethnic group & $\mathrm{p}=0.007^{1}$ & & & \\
\hline Mapuche & 3.7 & 3.5 & 15.1 & 4.5 \\
\hline Non Mapuche & 96.3 & 96.5 & 84.9 & 95.5 \\
\hline Read labels & $\mathrm{p}=0.026^{1}$ & & & \\
\hline Always & 6.4 & 2.9 & 13.2 & 7.5 \\
\hline Generally & 33.9 & 25.1 & 30.2 & 43.3 \\
\hline Occasionally & 42.2 & 55.6 & 37.7 & 29.9 \\
\hline Almost never & 11.9 & 12.9 & 13.2 & 16.4 \\
\hline Never & 5.5 & 3.5 & 5.7 & 3.0 \\
\hline Variety of oil & $\mathrm{p}=0.001^{1}$ & & & \\
\hline Sunflower & 34.9 & 35.7 & 39.6 & 34.3 \\
\hline Olive & 3.7 & 6.4 & 7.5 & 23.9 \\
\hline Grape seed & 0.9 & 0 & 0 & 0 \\
\hline Soy bean & 0.9 & 0.6 & 3.8 & 1.5 \\
\hline Vegetal & 59.6 & 57.3 & 49.1 & 40.3 \\
\hline
\end{tabular}

${ }^{1} \mathrm{p}$ value, is the asymptotic significance (bilateral) obtained in Pearson $\chi^{2}$ Test.

oil with GM that increases calcium intake and reduces production costs. This group was the only one that had positive preference numbers for the price levels, and they increased with the increasing price, suggesting an association between higher price and superior quality (Table 2). Group 4 had a lower proportion of families with one or two members (13.4\%) and a conservative lifestyle (44.8\%), and higher proportions of individuals who have an innovative lifestyle (25.4\%), generally read food labels (43.3\%) and regularly consumed olive oil (23.9\%), and have lower consumption of vegetable oil (Table $3)$. These results indicate that this group is the consumers who are sensitive to type of GM and price and prefer to pay higher prices.

The smallest group (Group 3) represented $13.2 \%(n=53)$ of the sample and assigned high importance to the type of GM (75.8\%), which was significantly higher than for Groups 1 and 4 but lower than for Group 2. It was the only one that rejected oil without GM and preferred oil with GM that increases the calcium supply, 
which was significantly higher than the other groups. This group showed the highest preference for the oil with GM that reduces the use of pesticides, which was significantly higher than the rest of the groups. Similarly to the other segments, they rejected GM that reduces the cost of production (Table 2). The Group 3 had a greater proportion of people of Mapuche origin (15.1\%) and that always checked food labels (13.2\%) (Table 3). According to this result, this group can be considered the consumers that are sensitive to type of GM and prefer TF that increases nutrition and benefits the environment.

\section{Discussion}

According to the results obtained, the type of genetic modification was more important than the price to consumers of Temuco when deciding the kind of oil to purchase. Even when consumers preferred the non-transgenic product, they did not reject all kinds of GMs.

In Temuco, four groups were established regarding the importance assigned to the type of GM and according to the attitude of the consumers towards the different kinds of GM in a food of vegetable origin. This confirmed that the attitudes towards biotechnology depend upon the type of GM performed (Nayga et al., 2006, Frewer et al., 2004). In this study, Pearson and Kendall's correlation coefficients showed adequate goodness of fit of the conjoint model, and the order obtained corresponded to the global order of the interviewee (Hair et al., 1999). In this context, for the whole cohort and for two of the four defined groups (Groups 2 and $3 ; 56.0 \%$ ), the type of GM clearly determined the consumer's decision, due to a markedly higher relative price than the actual price of the product ( 85.3 and $75.8 \%$, respectively). Even though the type of GM was important in Groups 1 and 4 (44.0\%), the importance of the price was relatively high (44.4 and $48.7 \%$, respectively), suggesting that consumers combine both attributes when choosing products. However, these results confirm the importance of the presence of GM in foods purchased in the central and southern areas of Chile (Schnettler et al., 2008a, 2008b).
The preferences for the levels of GMs agree with previous studies showing that the majority of consumers prefer food without GMs (Terawaki, 2008; Ganiere et al., 2006; Caporale and Monteleone, 2004; Mucci et al., 2004). However, the segmentation criteria used in this survey, based on the conjoint analysis and hierarchical cluster analysis techniques, allowed us to establish significant differences between the segments according to the purchasing behavior of the consumers. The preference for oil without GM was noticeably higher only for Groups 1,2 , and $4(86.8 \%)$, which is similar to results of previous studies performed on milk and tomato sauce in Chile (Schnettler et al., 2008a, 2008b). Still, it is important to note that in the above-mentioned investigations, the proportion of consumers who accepted TF was higher than in the present study (Schnettler et al., 2008a, 2008b).

The predominant preference for non-transgenic oil has other implications because, among the alternatives presented in the questionnaire, this alternative was included only with the highest price $\left(\$ 1,020 \mathrm{~L}^{-1}\right)$. Even though the results show that consumers (Groups 1, 2, and 3) preferred alternatives with lower prices, consumers favored the oil without GM even though its price was higher. Therefore, it is possible to suggest that the lower price could not compensate for the risk of consuming transgenic oil for these consumers. Similar results have been previously reported in Italy and Japan (Terawaki, 2008; Caporale and Monteleone, 2004), although they differed from studies performed in New Zealand and the USA (Kaye-Blake et al., 2005; Hossain et al., 2003). Price could be an important sign of quality when a certain risk is perceived in choosing incorrectly; therefore, consumers reject cheap products to avoid the risk of dissatisfaction with the purchase (Kotler, 2002), a behavior that was observed in Group 4, which preferred to pay the highest price.

The acceptance of oil with GM that reduces the usage of pesticides across the entire cohort and for Groups 2, 3, and 4 and the general rejection of oil with GM that reduces production costs suggest that consumer preference for GM food depends upon the type of genetic manipulation performed (Kaye-Blake et al., 2005). Moreover, it confirmed 
that if a TF generates benefits for the environment (i.e., decreases the use of pesticides), it would compensate for the risk perceived by the consumers, resulting in a positive attitude towards the GM food, and this behavior has been observed in other countries (Ganiere et al., 2006; Kaye-Blake et al., 2005; Napier et al., 2004; Lähteenmäki et al., 2003; Mucci and Hough, 2003).

However, it is possible that the preference for this type of GM indicates that consumers perceive this product as healthier, due to the possible adverse health effects of pesticides and its residues in food, an aspect that should be corroborated in upcoming investigations.

In some developing countries, the results obtained agree with the positive attitude towards TFs. In these studies, consumers considered the consumption of TFs to be beneficial (Kimenju and De Groote 2008; Pachico and Wolf, 2002; Zhong et al., 2002). In this regard, Curtis et al. (2004) related the highest TF acceptance in developing countries to concerns about the availability and nutritional content of food in these nations, along with a lower risk perception in the population. The higher potential yields and/ or greater nutritional contents of TF would be beneficial for increasing the availability of food and preventing nutritional problems due to deficits in nutrients, vitamins, or minerals. This kind of positive attitude towards TFs that have a direct benefit for the consumer (Hossain et al., 2003; Lähteenmäki et al., 2003), such as higher nutritional value or contents of vitamins and minerals (Kaye-Blake et al., 2005; Mucci et al., 2004; Lähteenmäki et al., 2003), was found only for Group 3 (13.2\%) in this study. Consumers of this group showed a higher preference for oil with GM that increases calcium content and rejected oil without GM. For the rest of the cohort, the negative attitude towards TF was not compensated for by health benefits, similarly to that previously reported in Nordic countries (Grunert et al., 2001). The attitude of Group 3, along with the rejection of the three types of GM of Group 1, corroborates the presence of groups both in favor of and against TFs in developed countries (Boecker et al., 2008; Christoph et al., 2008, Ganiere et al., 2006).
The composition of the four groups of consumers obtained in this investigation confirms that acceptance of TF relates to the size of the household and lifestyle (Schnettler et al., 2008a, 2008b; Nayga et al., 2006; Hossain et al., 2003). However, it was not related to gender, age, or educational level (Christoph et al., 2008; Kimenju and De Groote, 2008; Schnettler et al., 2008b; Ganiere et al., 2006; Nayga et al., 2006; Mucci et al., 2004; Napier et al., 2004; Hossain et al., 2003). It was also not related to the presence of children and their ages (Schnettler $e t$ al., 2008ab), the socioeconomic group, or area of residence (Schnettler et al., 2008b). Nevertheless, this paper studied the acceptance of different types of GM, which sets it apart from previous investigations.

The characterization of the groups also corroborated the relationship between acceptance of TF and reading of the labels prior to purchase, but it did not corroborate the associations with access to information and TF awareness of the consumer (Schnettler et al., 2008a, 2008b). As part of the sample used in this investigation, the proportion of people who already had information about TF $(73.5 \%)$ was higher than what was previously determined in Temuco and Talca (Schnettler et al., 2008a, 2008b). However, knowledge about TF continues to be low, and the general approval of including information about the use of GM ingredients on food labels persists (Schnettler et al., 2008a, 2008b).

It is remarkable that the Mapuche population in Group 3 was the only group that preferred GM oil with a GM that increases calcium content. This result could be associated with the inadequate consumption of milk detected in people that belong to this ethnicity in Araucanía (Peredo and Barrera, 2005). It is also interesting that a low proportion of Group 1 consumers (3.7\%) habitually use olive oil. In contrast, Group 4 showed a higher proportion of consumers who habitually use olive oil (23.9\%), which normally has a higher price on the market. This would explain the higher preference of Group 4 for the higher price and the higher rejection of Group 1 at the same time. 
Even though the majority of consumers of Temuco favor oil without GMs (86.8\%), they have positive attitudes towards GMs that belong to the first generation of genetically modified organisms (GMO) focused on the incorporation of productive characteristics that benefit the producers (i.e., resistance to insects and tolerance to herbicides), but this also confers direct benefits for the environment and secondary benefits for the consumer, who then consume a product with less pesticide residue. Acceptance was lower for GMs of the second generation of GMOs that incorporate features that benefit the consumer (i.e., higher contents of vitamins and antioxidants). This could be associated with lower consumer awareness about the second generation of GMOs, and this also should be explored in future investigations.

\section{Acknowledgments}

The results presented were obtained as part of the research funded by the Project Fondecyt 1080146.

\section{Resumen}

B. Schnettler, A. González, R. Avila, H. Miranda, J. Sepúlveda y M. Denegri. 2010. Preferencia de aceite con distintos tipos de modificaciones genéticas en Temuco, Región de La Araucanía, Chile. Cien. Inv. Agr. 37(1):17-28. Considerando que las actitudes respecto a la biotecnología dependen del tipo de modificación realizada, se estudió la importancia del tipo de modificación genética (MG) en la compra de aceite en consumidores de Temuco (Región de La Araucanía, Chile) y la existencia de diferentes segmentos de mercado, mediante una encuesta a 400 personas. Utilizando análisis conjunto se determinó que el tipo de MG (70,3\%) fue más importante que el precio (29,7\%). Mediante análisis de conglomerados jerárquicos se diferenciaron cuatro segmentos, pero en todos fue más importante el tipo de MG. Dos grupos prefirieron al aceite sin $\mathrm{MG}$ y el aceite con MG para reducir el uso de pesticidas y rechazaron el aceite MG para aumentar el contenido de calcio, de éstos el mayoritario $(42,8 \%)$ prefirió pagar el menor precio mientras el otro $(16,8 \%)$ prefirió el precio mayor. Un grupo $(27,2 \%)$ rechazó todos los tipos de MG. El grupo minoritario (13,2\%) rechazó el aceite sin MG, prefirió el aceite MG para reducir el uso de pesticidas y el aceite MG para aumentar el calcio. Todos los grupos rechazaron el aceite MG para reducir costos de producción. Los grupos se diferenciaron según tamaño de la familia, estilo de vida, etnia, lectura de las etiquetas de los alimentos y variedad de aceite consumida habitualmente. La ausencia de MG en aceite es una condición deseable para la mayoría de los consumidores $(86,8 \%)$, sin embargo, una alta proporción $(72,8 \%)$ aceptaría aceite $\mathrm{MG}$ que reduzca el uso de pesticidas.

Palabras clave: Aceite, alimentos transgénicos, segmentación de mercado, tipo de modificación genética.

\section{References}

Anónimo. 2004. Mapa Socioeconómico de Chile. Adimark, Investigación de Mercados y Opinión Pública. Santiago, Chile. Available online at: http://www.adimark.cl (Website accessed: April, 2005).

Boecker, A., J. Hartl, and G. Nocella. 2008. How different are GM food accepters and rejecters really? A means-end chains application to yogurt in Germany. Food Quality and Preference 19: 383-394.

Caporale, G., and E. Monteleone. 2004. Influence of information about manufacturing process on beer acceptability. Food Quality and Preference 15: 271-278.

Christoph, I., M. Bruhn, and J. Roosen. 2008. Knowledge, attitudes towards and acceptability of genetic modification in Germany. Appetite 51: $58-68$ 
Curtis, K.R., J.J. McCluskey, and T. Wahl. 2004. Consumer acceptance of genetically modified food products in the developing world. AgBioForum 7(1\&2): 70-75.

Da Costa, M.C., R. Deliza, A. Rosenthal, D. Hedderley, and L. Frewer. 2000. Non conventional technologies and impact on consumer behavior. Trends in Food Science \& Technology 11: 188193.

Fernández, A. 2002. Investigación y Técnicas de Mercado. Primera edición. Editorial Esic, Madrid, España. 273 pp.

Frewer, L., J. Lassen, B. Kettlitz, J. Scholderer, V. Beekman, and K. Berdal. 2004. Societal aspects of genetically modified foods. Food and Chemical Toxicology 42: 1181-1193.

Ganiere, P., W. Chern, and D. Hahn. 2006. A continuum of consumer attitudes toward genetically modified foods in the United States. Journal of Agricultural Resource Economics 31:129-149.

Gil, L., V. Martínez, C. Irarrázabal and C. Martínez. 2001. Aceptación pública de la biotecnología y de los alimentos transgénicos. Ambiente y Desarrollo 17: 52-59.

Grunert, K., L. Lähteenmäki, N. Nielsen, J. Poulsen, O. Ueland, and A. Åström. 2001. Consumer perception of food products involving genetic modification: results from a qualitative study in four Nordic countries. Food Quality and Preference 12: $527-542$.

Hair, J., R. Anderson, R. Tatham and W. Black. 1999. Análisis Multivariante. Quinta edición. Prentice Hall Internacional, Inc., Madrid, España. 832 pp.

Hossain, F., B. Onyango, B. Schilling, W. Hallman, and A. Adelaja. 2003. Product attributes consumer benefits and public approval of genetically modified foods. International Journal of Consumer Studies 27: 353-365.

Kaye-Blake, W., K. Bicknell, and C. Saunders. 2005. Process versus product: wich determines consumer demand for genetically modified apples? Australian Journal of Agricultural Resource Economics 49: 413-427.

Kimenju, S., and H. De Groote. 2008. Consumer willingness to pay for genetically modified food in Kenya. Agricultural Economics 38(1): 35-46.

Kotler, P. 2002. Dirección de marketing. Conceptos esenciales. Primera edición. Pearson Educación, Juárez, México. 351 pp.

Lähteenmäki, L., K. Grunert, Ø. Ueland, A. Åström, A. Arvola, and T. Bech-Larsen. 2003. Accepta- bility of genetically modified cheese presented as real product alternative. Food Quality and Preference 13:523-533.

Lea, P., M. Rodbotten, and T. Naes. 1997. Analysis of variance for sensory data. First edition. John Wiley \& Son, Chichester, United Kingdom. 102 pp.

Mucci, A., and G. Hough. 2003. Perceptions of genetically modified foods by consumers in Argentina. Food Quality and Preference 15:43-51.

Mucci, A., G. Hough, and C. Ziliani. 2004. Factors that influence purchase intent and perceptions of genetically modified foods among Argentine consumers. Food Quality and Preference 15: 559-567.

Napier, T., M. Tucker, C. Henry, and S. Whaley. 2004. Consumer attitudes toward GMOs: the Ohio experience. Journal of Food Science 69: 69-76.

Nayga, R. Jr., M. Fisher, and B. Onyango. 2006. Acceptance of genetically modified food: comparing consumer perspectives in the United States and South Korea. Agricultural Economics 34: 331-341.

ODEPA. 2007. Estadísticas y precios / Series de precios / Avance mensual. Oficina de Estudios y Estadísticas Agropecuarias, Gobierno de Chile, Santiago, Chile. Available online at: http://www. odepa.gob.cl/odepaweb/servlet/sistemas.precios. ServletPreciosScr;jsessionid=644B59C4D5715 73E9AB6A8B4EF0BD11C (Website accessed: January, 2008).

Pachico, D., and M. Wolf. 2002. Attitudes toward genetically modified food in Colombia. $6^{\text {th }}$ International ICABR Conference. Ravello, Italy.

Peredo, S., and C. Barrera. 2005. La monoculturización del espacio natural y sus consecuencias sociocultural en una comunidad rural indígena del sur de Chile. Revista de Antropología Experimental 5(15): 1-10.

Schnettler, B., O. Sepúlveda, and D. Ruiz. 2008a. Aceptación diferenciada de alimentos transgénicos de origen vegetal y animal en la Región de La Araucanía, Chile. Ciencia e Investigación Agraria 35(2): 169-180.

Schnettler, B., O. Sepúlveda, D. Ruiz, P. Catalán, and N. Sepúlveda. 2008b. Conocimiento y aceptación de leche genéticamente modificada en consumidores de la Región del Maule, Chile. Economía Agraria 12: 15-29.

Terawaki, T. 2008. Can information about genetically modified corn and its oil have significant effects on Japanese consumers' risk perception and their valuation? AgBioForum 11(1): 39-47. 
Williams, P.R.D., and J.K. Hammit. 2001. Perceived risks of conventional and organic produce: Pesticides, pathogens, and natural toxins. Risk Analysis $21: 319-330$.
Zhong, F., M.A. Marchant, Y. Ding, and K. Lu. 2002. GM foods: A Nanjing case study of Chinese consumers' awareness and potential attitudes. AgBioForum 5(4):136-144. 